Behavior and Social Issues, 19, 7-47 (2010). (C) Lyle K. Grant. Readers of this article may copy it without the copyright owner's permission, if the author and publisher are acknowledged in the copy and the copy is used for educational, not-for-profit purposes.

\title{
SustainabiLity: From ExCess to Aesthetics
}

\author{
Lyle K. Grant \\ Athabasca University
}

\begin{abstract}
Sustainability is defined as the operation of a steady-state economy in which natural resource inputs and waste-product outputs are held constant. Key issues in attaining sustainability are addressing the problems of overconsumption of resourceintensive reinforcers, underconsumption of resource-light reinforcers, and lack of consumption skills that yield an enduring source of intrinsically reinforcing challenges and pleasures. Behavioral impediments to a sustainable society are described together with opportunities to achieve it. Opportunities emphasize sustainable futures people will find appealing rather than austere. These opportunities include a replacement of consumer culture with alternative value systems, embodied in John Stuart Mill's art of living, Tibor Scitovsky's cultural reawakening, B. F. Skinner's arts-based utopia, voluntary simplifiers, and the aesthetically-based values of Bohemian communities.
\end{abstract}

KEYWORDS: sustainability, overconsumption, steady-state economy, positional economy, advertising

Sustainability refers to our ability to engage in behaviors that both adequately reinforce the behavior of the current population and are repeatable over long time spans without having harmful effects on future generations (cf., United Nations, 1987). For most of human history until the early 19th Century, the human population was relatively small, limited by available methods of growing food and extracting natural resources. However, with the onset of the industrial revolution and the attendant use of fossil fuels an exponential growth economy has prevailed in which each succeeding generation of humans has increased in size and consumed increasing amounts of the Earth's finite resources (Schafer, 2008). This progressive increase in consumption has made sustainability a key issue of our time. As M. King Hubbert (1981) summarized: "Perhaps the foremost problem facing mankind at present is that of how to make the transition from the present exponential-growth phase to the near steady state of the future in as noncatastrophic a progression as possible" (p. 1007).

A knowledge of behavioral processes is central to understanding and solving the problems of sustainability. Making a transition from a world in which finite natural resources are used in ever-increasing quantities to one in which resource supply is more-or-less fixed is a behavioral problem of engaging in a form of 
collective self-control. This makes it essential to consider sustainability and associated environmental issues from a psychological/behavioral perspective (Geller, Winett, \& Everett, 1982; Koger \& Winter, 2010; Rumph, Ninness, McCuller, \& Ninness, 2005; Wachtel, 1989).

The purpose of the present paper is to examine the behavioral challenges and opportunities we face in creating a sustainable culture. Sustainability is initially defined in terms of a steady-state economy. The growth economy in the developed world is described as one of overconsumption of resource-intensive reinforcers and underconsumption of resource-free and resource-light reinforcers. Challenges in making a transition from our current growth economy to a steady state economy are examined. Selected opportunities for meeting these challenges are also discussed. Selected challenges and opportunities surveyed here are limited to psychological and behavioral factors rather than, for example, other important considerations including geographical localization (Rubin, 2009) or recycling waste products (McDonough \& Braungart, 2002).

\section{Sustainability as a Steady-State Economy}

Sustainability has become a popular term, yet the term is often used with no clear definition (Princen, 2005). The authors of the Brundtland Report of the World Commission on Environment and Development (United Nations, 1987) created a widely cited definition of sustainable development: "development that meets the needs of the present without compromising the ability of future generations to meet their own needs."

A limitation of the WCED definition is that it lacks specificity, which can be overcome in part through the recognition that the Earth's natural resources, essential for human well-being, are finite (Daly, 1996; Hardin, 1993; Meadows, Randers \& Meadows, 2004; Schumacher, 1989; Speth, 2008). Consumption has grown to the point at which multiple important boundaries for safe planetary operation are in danger of being exceeded (Rockström et al., 2009). Some experts (e.g., Deffeyes, 2006) believe that oil supply has already reached a worldwide production peak, whereas others forecast a peak within the next 10 years (Farzad, 2008; Leggett, 2005; Rubin, 2009). Coal is often described as an abundant resource with reserves equivalent to over a 250-year supply, but a committee of the National Research Council (2007) concluded that "only a small fraction of previously estimated reserves are economically recoverable" (p. 5). Laherrère (2007) has estimated that a peak in world coal production will occur in about 2050. If they continue on their present course, intensive fishing practices are expected to result in a collapse in the world's fish population by the middle of the current century (Worm et al. 2006). Limits on the capacity of the environment to 
absorb $\mathrm{CO} 2$, without heating to damaging levels, is also reaching or exceeding key limits (Intergovenmental Panel on Climate Change, 2007). Hansen et al. (2008) specified that it is essential that atmospheric carbon dioxide be reduced to at least 350 parts per million from its current level of 385 parts per million and warned that exceeding the 350 level more than temporarily runs the risk of irreversible warming. The peak production of many important industrial metals has already occurred and will continue to occur during this century (Bardi, 2008; Bardi \& Pagani, 2007). Agricultural production is reaching limits it will be difficult to exceed (Brown, 2004). Fresh water, essential for basic human needs, has grown increasingly scarce (Rogers, 2008). It is expected that two-thirds of the world's population will live under water-stressed conditions by 2025 (UNESCO, 2009). Another threat to sustainability is the increasing use of natural resources among developing nations, where enhanced resource use is required to provide basic necessities (United Nations, 1987). If all the world's countries consumed natural resources at the rate of the United States or the United Arab Emirates, 4.5 Earths would be required (Ewing et. al., 2008).

The current world economy is based on the assumption of perpetual economic growth in which use of finite natural resources, as well as the human population, constantly increases over time (Speth, 2008). The logical foundations of this assumption are seldom examined. According the State of the World report of the Worldwatch Institute (Halweil et al., 2004) "Endless economic growth driven by unbridled consumption has been elevated to the status of a modern religion" (p. 96). However, the finite supply of natural resources requires not a growth economy, but one in which natural resource reinforcers are held constant at a level that does not exceed the Earth's carrying capacity. Nineteenth-century economists understood that resource limits would eventually necessitate such an economy and economist Herman Daly and his colleagues (Daly, 1991, 1996; Daly \& Cobb, 1994; Daly \& Farley, 2004) have revived this understanding in the modern era with their advocacy of a steady-state economy. Several early economists envisioned the inevitable prospect of a no-growth economy, with "unaffected aversion," in John Stuart Mill's (1909/2000) words. Mill himself however believed that a steady-state economy, which he called a "stationary state," would be an improvement over the growth economy that prevailed in his time.

In a steady-state economy a key concept is the notion of throughput, defined as "the flow of natural resources from the environment, through the economy, and back to the environment as waste" (Daly \& Farley, 2004, p. 6). Within a steadystate economy throughput is held constant: The economy functions with a set of natural-resource reinforcer inputs that remains constant over time. Holding 
throughput constant in turn keeps rates of economic behavior, including consumption and production, at similarly constant levels. In contrast, in a growth economy natural-resource reinforcer supply continually increases, as does production and consumption, until the system collapses either because the natural resource inputs are exhausted or because the rate of waste product emissions exceeds the environment's capacity to absorb them. In order to be sustainable, throughput must be set at a level at which natural-resource supply can be maintained indefinitely over time and at which the environment can absorb the waste products. In a steady-state economy technological progress can improve the efficiency of use of natural-resource reinforcers, but without increasing throughput. Although a steady-state economy has a zero rate of throughput growth, it is not to be confused with either the periodic economic hardships of no growth within a growth economy or a zero rate of GDP growth (Daly, 1996).

Sustainability may be defined as practices that are consistent with a steadystate economy, in which rate of usage of natural-resource reinforcers (i.e., throughput) is held at a constant level to maintain a similarly constant rate of both aggregate economic activity and output of waste products. It is of course essential that the ongoing rate of throughput be set at a level that does not exceed either resource supply or environmental-absorption capacity. In this way a steady-state economy functions within the limits of the Earth's carrying capacity.

\section{Overconsumption, Underconsumption and Consumption Skills}

Contemporary concern with issues of the environment and sustainability have led to a focus on the problem of overconsumption (e.g., McKibben, 2007; Nevin, 2005; Skinner, 1987; Swim et al., 2009). Many of the products consumed in developed economies are unnecessary resource-intensive luxuries coveted due to competitive contingencies, including competitive status-seeking (Frank, 1999; Schor, 1998). For example a large home with seldom-used space requires substantial inputs of energy and other resources in its construction and operation. It is an expensive resource-intensive alternative to a smaller home in which space is fully used. In order to afford a large home, the average person must work for many months or years in employment that is often itself resource-intensive. This cycle in which unnecessary resource-intensive consumption reinforces resourceintensive work typifies economic activity in developed countries, leading to overwork (Hayden, 1999; Hunnicutt, 1988; Linder, 1970; Reid, 1995; Schor, 1992) and overspending (Frank, 1999; Schor, 1998). The cycle also contributes to climate change: Rosnick and Weisbrot (2006) found for example that if U.S. work hours were reduced to European levels, the lessened economic activity would 
have been sufficient to meet the CO2 reductions designated in the 1997 Kyoto agreement.

Perceptions of cultural overconsumption are sometimes influenced more by relative changes in consumption patterns rather than by stronger secular trends. Growth economies are inherently unstable and cyclic, resulting in periods of debtfunded overconsumption followed by periods of forced savings and an unwinding of debt (Minsky, 1992). We are currently in a contraction phase of the growth economy's economic cycle, leading some to conclude that an enduring economic moderation and frugality have supplanted overconsumption and that criticisms of a culture of overconsumption are outdated. Temporary economic contractions, themselves an undesirable by-product of prior overconsumption, can provide the illusion that the growth economy's unsustainable demand for resources and outflow of waste products has ceased.

Sustainability is often framed entirely as a problem of overconsumption, but this view restricts potential solutions to those involving abstention and self-denial. A key parallel problem is the underconsumption of reinforcers that do not tap throughput substantially. The behavior of people in developed economies is broadly analogous to a concurrent schedule of reinforcement in which in one component resource-intensive reinforcers maintain responding and in the other component resource-free or resource-light reinforcers do so. In reflecting on the inevitability of a steady-state economy, Mill (1909/2000) anticipated the arrival of a time when society would make a changeover from material resource reinforcers to resource-free and resource-light reinforcers:

... a stationary condition of capital and population implies no stationary state of human improvement. There would be as much scope as ever for all kinds of mental culture, and moral and social progress; as much room for improving the Art of Living, and much more likelihood of its being improved, when minds ceased to be engrossed by the art of getting on. (Book IV, Chapter VI, para. 2)

The alternative reinforcers Mill alludes to as part of the art of living are extraordinarily important because they provide a positive incentive for sustainable living. Schor (1995) argues that well-intentioned appeals to adopt austere lifestyles on environmental or moral grounds are less likely to change behavior than offering the alternative of a higher-quality life. Likewise, Skinner (1978) advised against rhetorical methods that "frighten people rather than offer them a world to which they will turn because of the reinforcing consequences of doing so" (p. 13). Achieving sustainability hinges on how effectively advocates can portray an attractive future based on stable resource consumption and highlight 
existing subcultural practices that, if properly scaled, can form the basis of such a future. For his part Skinner outlined an appealing potential future in Walden Two. Although more controversial features of the novel have traditionally been the focus of attention, it can also be understood as a blueprint for ecological health (Altus \& Morris, 2004). Skinner (1976) described a community, inspired by Thoreau's original Walden, in which people reduced "some of the things they normally consume to eliminate some of the aversive labors otherwise required" (Evans, 1981, p. 46). In Walden Two resource-intensive work is reduced to four hours per day, allowing much of the remainder of daily life to be left to the pursuit of acquired tastes in the literary, visual and performing arts (Skinner, 1976, Chapter 11). For his part Mill (1979/2004) believed that a key to the success of humankind was through the development of a cultivated mind, which would allow people to enjoy pleasures previously denied to them. Not restricted to a leisure class, Mill insisted that such a mind, could be "the inheritance of every one born in a civilized country," and is close to the ideals of Walden Two as it:

... finds sources of inexhaustible interest in all that surrounds it; in the objects of nature, the achievements of art, the imaginations of poetry, the incidents of history, the ways of mankind, past and present, and their prospects in the future." (Chapter II, para. 13)"

Skinner and Mill were interested in expanding the role of artistic creation and appreciation in daily life as well as fostering general intellectual culture, but a higher quality of life can also encompass other widely appealing resource-light and resource-free activities. Like Mill and Skinner, Scitovsky (1992) prized intellectual, artistic, and literary reinforcers, but more explicitly extended the domain of desirable culture to include reinforcing behaviors, such as conversation and other day-to-day activities:

The word "culture" usually makes people think of the ability to enjoy literature, music, painting, and other fine arts whose enjoyment takes effort and time to learn, although the appreciation and enjoyment of food, sports, games of skill and card games, political, economic, and scientific news, and so on are also learned skills and must therefore be included in the definition of culture. (pp. 226-227)

For Scitovsky, a key problem with modern society is that a large range of important and powerful reinforcers are denied to people because they lack requisite consumption skills. The behaviors composing the art of living and the acquired aesthetic tastes in Walden Two are consumption skills that are learned, 
often with time and some difficulty, but once acquired open new domains of reinforcing challenges and pleasures. Learning to enjoy literature, for example, is often not effortless but once acquired establishes the stored rewards of centuries of literary output (Grant, 2005; Nell, 1988).

From Scitovsky's (1989a, 1992) perspective, consumption is an inevitable and ongoing everyday process rather than something to be avoided as necessarily undesirable or unsustainable. Scitovsky maintained that the problem of material overconsumption is rooted in the lack of skilled consumption. Reading a good book, listening to music, intelligent conversation, etc. are all resource-light forms of consumption that require the consumption skills involved in literary, musical and conversational appreciation. For Scitovsky this skilled consumption also entails relative reinforcer effectiveness: valuing reinforcers such as literature, music, and conversation as worthy and superior alternatives to resource-intensive material consumption. Acquiring consumption skills in part requires motivating operations (Michael, 2004) that establish the relative effectiveness of appropriate reinforcers. Without acquisition of consumption skills, people generally fall into a pattern of engaging in resource-intensive work to consume resource-intensive material goods.

In the material that follows, overconsumed reinforcers refer to reinforcers whose current level of consumption is not sustainable insofar as that level cannot be supported within a steady-state economy. Underconsumed reinforcers refer to reinforcers whose current level of consumption can be increased and still support a steady-state economy. Ultimately society will have to come to grips with which precise levels of consumption are sustainable including, for example, what amount of motorized transportation can be supported by renewable sources of energy (e.g., Gilbert \& Perl, 2008). For our present purposes though, a rule of thumb is that underconsumed reinforcers are free-time, non-income producing activities that do not draw on natural resources or do so only in a relatively limited way. The most important underconsumed reinforcers are those that require significant consumption skills that lead to progressive increases in intrinsic reinforcers with increasing skill proficiency. Increasing the accessibility and effectiveness of underconsumed reinforcers holds the promise of breaking the cycle of work-to-consume (Hunnicutt, 1988; Schor, 1992) while at the same time increasing the quality of day-to-day life.

What are described here as underconsumed reinforcers have played a part in rich and diverse historical traditions. In many indigenous cultures people find fulfillment from social relationships and the environment, values that are eroded with the encroachment of Western consumerism (Norberg-Hodge, 1992). Many religious perspectives maintain that an ideal life is one in which participation in 
prayer, meditation, charity and group celebrations are favored over the pursuit of material wealth (de Botton, 2004; Kaza, 2000, 2005; Shi, 1985). Thoreau (1854/1995) saw luxuries as "hindrances to the elevation of mankind" (p. 8) and believed that if people properly understood the realities of life "music and poetry would resound along the streets" (p. 62). For centuries communities of Bohemian artists and writers have shunned the bourgeois accumulation of money in favor of aesthetic reinforcers (de Botton, 2004; Wetzsteon, 2002). The counterculture of the 1960s and early 1970s (Reich, 1970; Roszak, 1968) likewise devalued many economic reinforcers and instead explored lifestyles focused on art, music and unconventional politics. The voluntary simplicity movement (Elgin, 1993; Etzioni, 1998; Maniates, 2002) is a diverse contemporary subculture that forgoes many material goods yet seeks out resource-light pleasures (McBride, 1997). The labor movement's successful campaign for shorter working hours during the 19th and early 20th centuries (Hayden, 1999; Hunnicutt, 1988) represents a struggle to obtain reinforcers other than those that money can buy. Putnam's (2000) Bowling Alone, highlighted the importance of social reinforcers inherent in family and community activities and associated benefits to both individuals and the larger society. He documented the decline and relative underconsumption of these activity reinforcers and has related these declines to increases in crime, poverty, and a range of other undesirable consequences. Csikszentmihalyi (1990) contended that resource-light structured reinforcing activities are central to a personal fulfillment.

Increasing the relative time allocation to pursuit of resource-light and resource-free reinforcers represents at once the key challenge to sustainability of developed economies and a major opportunity for the behavioral sciences to make a distinctive contribution to creating a sustainable society. Whereas economics and the business community generally limit their domain of analysis to reinforcers (i.e., incentives and products) that have a quantifiable dollar value (Scitovsky, 1973b), behavior science extends its scope to include all reinforcers capable of maintaining behavior. Inducing people to shift more of their time and behavior to acquiring these noneconomic reinforcers is a key to the creation of a sustainable society.

\section{Transition to Sustainability as a Behavioral Process: Challenges}

Shifting from an unsustainable growth economy to a steady-state economy can be understood in terms of both avoiding a much worse world and advancing to a more reinforcing one. In avoidance responding, engaging in a behavior prevents or postpones an aversive consequence (a harmful event or set of events), whereas failure to engage in the behavior produces the aversive consequence. In 
these broad terms, actions and policies that put a steady-state economy into place represent an avoidance response, which will prevent the harmful consequences of exceeding the Earth's carrying capacity. As emphasized in the work of Mill, Skinner and Scitovsky, a steady-state economy also offers the potential for a more reinforcing world though a transition to a culture of acquired tastes and pleasures.

The growth economy represents a diverse set of interlocking practices (Glenn, 1991; Glenn \& Malott, 2004) that support ever-increasing resource use. Long working hours, low-density suburban housing, dependence on fossil-fuel transportation, product marketing practices, and the fractional-reserve banking system (Daly \& Farley, 2004) are all examples of these interlocking practices. Although consumption is often portrayed as a matter of individual choice, Sanne (2002) described many interlocking practices that induce consumption simply because society fails to provide alternatives.

A complete treatment of replacing the growth economy with a steady-state economy would ideally address the entire set of interlocking practices that support growth. In this section the focus is more selective, restricted to important behavioral challenges. Challenges include: (a) the nonrecurring nature of the harmful consequences of unsustainable behavior; (b) the delay of the harmful consequences; (c) the nature of avoidance responding; (d) the variability in the anticipated delay of the harmful consequences; (e) reinforcer habituation; (f) a baseline of abnormal exponential growth and behavioral momentum; (g) efficiency; (h) the predicted aversiveness of a sustainability crisis; and (i) competing reinforcers.

\section{Harmful Nonrecurring Consequences}

People are highly capable of adapting to various types of environmental and other challenges once those challenges are encountered in concrete form rather than as an abstract idea (Grant, 2007; Swim et al., 2009). Most successful behavioral interventions are indeed based on simply giving people direct practice that allows them to acquire or perfect skills (e.g., Cooper, Heron, \& Heward, 2007; Martin \& Pear, 2003). The problem with economic growth and overconsumption is that direct practice is not possible because the harmful consequences only occur when shortages in a finite natural resource appear or the Earth's ability to absorb waste products is exceeded. Archaeological and other historical evidence indicates that several ancient cultures failed because they outgrew their carrying capacity or otherwise failed to adapt to changing environmental conditions (Diamond, 2005; Redman, 1999). However, these consequences were encountered only by people who lived centuries ago. As a result these conse- 
quences do not act directly upon anyone's current behavior and instead act only indirectly through application of derived rules or instructive analogies, weakening their relative effectiveness (Malott, 1986).

\section{Harmful Delayed Consequences}

The effectiveness of behavioral consequences on behavior change is lessened when they are delayed (Ainslie, 2001; Rachlin, 2000) and some of the harmful consequences of a growth economy are likely to be delayed by as long as several decades before they actually materialize. This principle is often described in terms of temporal discounting: The effectiveness of a consequence on behavior is lessened or discounted the more it is delayed. Sustainability is difficult in part because the consequences at issue are delayed and currently inapparent. Harmful effects such as climate change, overpopulation, shortages of fossil fuels and fresh water, are all delayed consequences that are less effective than they would be if they were current.

\section{The Nature of Avoidance Responding}

Even with practice avoidance responding is difficult to acquire because nothing immediately occurs following the response (Catania, 1998). Under avoidance contingencies the avoidance response merely maintains current conditions by preventing or postponing an aversive consequence. Failure to respond produces the aversive consequence, but its occurrence is also delayed. Implementing a steady-state economy, the avoidance response, would prevent the harmful effects of unsustainable practices, but no immediate prominent consequent advantages would be apparent to the public or to any political group opposed to a steady-state economy. In order to implement the avoidance response, a steady-state economy, resources, education, and effort must be mobilized. However, this mobilization must compete with efforts to solve many other important problems (e.g., economic recessions, crime, poverty, child welfare etc.) that are currently harmful.

Avoidance responding is often successfully acquired when it is preceded by escape responding, in which something does happen after the response: the escape response terminates the aversive stimulus. For example, once acquired as a response that escapes an acute water shortage, water conservation can be maintained as an avoidance response because it prevents future shortages (Geller, 1992). In escape responding, the learner receives practice in removing the aversive stimulus, which appears to facilitate learning how to prevent it as well. However, the nonrecurring nature of the harmful consequences of unsustainable 
practices means there is often no opportunity to learn to use a policy like a steadystate economy as an escape response.

\section{Variability in the Predicted Delay of the Harmful Consequences}

One influence that is seldom explicitly discussed and not well understood is the variability in the predicted delay of the aversive consequences of unsustainable practices. Both climate models and estimates of depletion of natural resources are widely variable in their predictions of when problems will occur. For example, some estimate that a peak in world oil production has already occurred, whereas others envision no oil peak for the foreseeable future (Grant, 2007). Avoidance responding was successful in addressing the Y2K computer problem, which included the possibility of an accidental nuclear war (Knelman, 1999) largely because the aversive consequences were scheduled to occur on a very specific deadline date. Neither global warming nor resource depletion can be precisely tagged with specific dates, which helps foster the view that their solutions can be postponed. Another complicating factor is that current use of energy and other resources is highly inefficient relative to even what current technologies can provide (Hawken, Lovins \& Lovins, 1999). Additional improvements in efficient technologies are likely to further postpone the aversive consequences, but by a time factor that is difficult to predict in advance.

Since the industrial revolution began technological advancement has been a wild card in foiling accurate predictions of future crises due to unsustainable practices. The impact of technology in improving agricultural and industrial productivity, communications, ability to extract fossil fuels, providing laborsaving machines, etc. has been impressive since the industrial revolution. During this time technological advancement has confounded certain predictions of a dire future. Malthus (1798/1998) for example was incorrect in his predictions of famines due to population growth outrunning the food supply because he did not anticipate the increased rate of technological advancement, as well as fossil-fuel use, that occurred just about the time he proposed his theory (Galor \& Weil, 1999; Hardin, 1993). Although Malthus is often cited and even derided as a prototype of a faulty predictor of the harmful effects of growth, his model correctly accounted for the relationship between population size and food supply during most of human history prior to the modern era (Galor \& Weil, 1999; Krugman, 2009). Some observers see the current technological era as anomaly in human history that has created a collective illusion that growth can continue indefinitely (Catton, 1982; Hubbert, 1981). 
The variable nature of the delay of projected onset of the aversive consequences of unsustainable practices is manifest in the successive predictions of M. King Hubbert, well known for issuing a correct 1956 prediction that the United States oil production would peak in 1970 (Hubbert, 1956). In making projections as new data became continuously available Hubbert altered his outlook several times, varying the projected delay of the aversive consequences of unsustainable practices. For example he initially discounted the potential contribution of solar energy because it was too highly dispersed. He nonetheless eventually came to regard electricity generation from photovoltaic and solar thermal technologies as a viable replacement for fossil fuels as a source of energy (Brenno, 2009) that would have the potential to "provide an environment for the flowering of a great civilization" (Hubbert, 1981, p. 1029). Changing projections of future prospects due to technological innovations can lead to dismissal of future predictions in general due to the operation of extinction of attending to predictions, but ongoing alterations of predictions are essential in data-based decision making. For his part, Hubbert's projection of a bright future for humanity was dependent on stabilization of the population and adoption of a steady-state economy: Adoption of even powerful renewable solar technologies without being coupled with a steady-state economy would produce consequences that he described as "not pleasant to contemplate" (Hubbert, 1981, p. 1029).

Current discussions of sustainability generally fail to recognize the intractably variable nature of predictions of the delay of the aversive consequences of unsustainable practices. Instead of trying to come to terms with the nature of the parameter, discussions are often mired in vituperation over the accuracy of individual predictions. A more helpful approach is to accept the nature of the variability-of-the-delay parameter and take a risk management approach (Grant, 2007; Hirsch, Bezdek, \& Wendling, 2005), to the issue by adopting an economy that will be sustainable whether a disastrous future is either impending or decades away.

\section{Reinforcer Habituation}

In reinforcer habituation, a reinforcer loses it effectiveness over time due to repeated application (Murphy, McSweeney, Smith, \& McComas, 2003). Habituation is a general problem for sustainability because loss of effectiveness of purchased goods or income can spur people to work for more income to purchase new products, whose effectiveness has not diminished due to habituation. Habituation or habituation-like processes are seen in surveys in which people rate whether particular goods are luxuries or "necessities" or as part of "the good life". 
For example, in 1973 a second car was rated as a "necessity" by only $20 \%$ of U.S. residents, but by 1996 this value had nearly doubled to 37\% (Schor, 1998). Likewise, from 1975 to 1991 a vacation home, swimming pool, and foreign travel showed large increases in the extent to which they were rated as "part of the good life" (Schor, 1998). Although designations of necessities and luxuries can be reversed during economic contractions (Pew Research Center, 2009), overall these data suggest that as income continues to rise in a standard growth economy people's definition of what is a necessity will continue to expand, producing increasing consumption of newly perceived necessities.

\section{Baseline of Abnormal Exponential Growth and Behavioral Momentum}

Due to the growing use of fossil fuels as well as the increase in the rate of technological progress, the era since the industrial revolution to the present has led to a rich rate and magnitude of reinforcement in developed societies. An effect of this infusion of wealth and resulting growth has been behavioral momentum, the resistance of behaviors to change (Nevin, 2005). This resistance to change in consumption makes it difficult to reduce the level of behaviors responsible for exponential growth in population, resource use and emission of harmful waste products. The rhetoric of political leaders continues to reflect resistance to change. Former President George H. W. Bush said "The American way of life is not negotiable" (quoted in Wheeler, 2004). President Obama shares this inertial stance, declaring in his inaugural address: "We will not apologize for our way of life, nor will we waver in its defense..." (Obama, 2009).

A manifestation of the growth economy in creating behavioral momentum is the perception that any decline or moderation in economic growth is abnormal. Yet as Hubbert (1981) observed:

... the events of the last two centuries, including exponential growth in industry and a nearly six-fold increase in the human population, instead of being the normal order of things, actually represent the most abnormal events in human history." (p. 1029)

Resistance to change due to affluence also occurs in the outlook ordinary people have on life and work. Hayden (1999) quoted a French worker's disdain for a 32-hour work week on the grounds that it is impossible to enjoy extra leisure time without money. For Hayden, this illustrates:

... how capitalism has created people with no identity beyond being worker-consumers, and it shows how dependent many of us have 


\section{GRANT}

become on the market to satisfy all our needs and wants. Although this dependency is clearly related to capitalism's generation of new "needs" and its hindering of the capacity of people to fulfill their needs and wants outside of the market, the problem also reflects a failure of the imagination. Surely we can still find ways to engage in leisure and provide our own amusements, just as people have done throughout history, without first having to generate income from the sale of our labour. (pp. 89-90)

Resistance to change due to affluence is particularly the enemy of imaginative and creative behaviors, which are defined in terms of change and the emergence of novel forms. Data show that the absence of customary reinforcement increases novel response variants, which are one of the sources of creativity (e.g., Epstein, 1993; Lalli, Zanolli, \& Wohn, 1994).

\section{Efficiency: Reduced Response Requirements per Reinforcer}

Reductions in the quantity of behavior required per reinforcer unit can be achieved either by improvements in efficiency or by lowering the cost of required resources. When less behavior is required to obtain the same quantity or frequency of reinforcement, this is widely regarded as a net benefit. Politically there is often little objection to enjoying the same reinforcers for less behavior or cost. Therefore much of the current focus of the United States Department of Energy for example is on improving the efficiency of energy use (The White House, 2009).

Although both improvements in energy efficiency and supply represent potential benefits, their impact is more complex than is generally regarded due to the operation of Jevons effects, also known as the Khazzoom-Brookes postulate (Saunders, 1992). Jevons (1866) found improving machine efficiency saves energy in the short term, but produces a rebound effect that increases energy use in the long term. The disparity between these short- and long-term effects is known as Jevons' paradox. For example, if a more efficient tractor is invented, it is possible to plow the same amount of land at lesser cost or more land at the same cost, so there is a tendency to plow more land and increase output and potential profits. The more efficient tractor therefore brings more land into production, supports a greater human population and increases economic growth. In the short-term, increased efficiency appears highly attractive as a means of reducing resource use, but in the long-term, improving efficiency increases the available reinforcement for the same behavioral requirement (i.e., same cost, same 
response magnitude, or same number of responses), resulting in greater use of the fuel-using machine along with greater use of fuel and other resources.

Advances in technology that provide energy at low cost have the same net effect as improvements in machine efficiency: The same amount of reinforcement is available for less behavior or cost. Advances in renewable energy sources are occurring and will accelerate as fossil fuels are depleted (Gilbert \& Perl, 2008). Technological breakthroughs in alternative energy sources (e.g., geothermal, oil shale recovery, nuclear fusion, increased solar cell efficiency, solar thermal technology, cellulosic and algae biofuels, etc.) would ostensibly lessen the aversiveness of a crisis of sustainability or even eliminate such a crisis. Although injection of a source of inexpensive energy into the economy would have the short-term effect of increasing the supply of energy, over the long-term such developments are likely to increase demand for energy due to Jevons' effects. Only within a steady-state economy, in which throughput is held constant, can efficiency improvements maintain or reduce resource-reinforcer requirements.

\section{Predicted Aversiveness of a Sustainability Crisis}

Unimpeded growth without countermeasures will eventually result in climate change and resource depletion, but perceptions of how harmful this will be vary widely. Although there is a consensus among climate scientists that global warming will have disastrous effects (Intergovernmental Panel on Climate Change, 2007), a minority believe warming observed to date is not due to carbon emissions (e.g., The National Post, 2009). Maibach, Roser-Renouf, and Leiserowitz (2010) found that people skeptical about global warming believe that there is little scientific consensus on the issue. Divergent perceptions are also prevalent with respect to the availability of energy. Some authorities foresee a future in which renewable energy sources power increasingly efficient vehicles and other machines, whereas others envision a cultural collapse (Catton, 1982; Kunstler, 2005) when carrying capacity is exceeded. This divergence of opinion leads many to the conclusion that there is no valid knowledge base and that therefore there is no clear problem (Deffeyes, 2005).

\section{Competing Reinforcers}

The growth economy is supported by a large variety of reinforcers. Even modest changes in the direction of a steady-state economy must compete with these powerful reinforcers. Selected examples of these reinforcers include those that work against consumption skills, the work ethic, positional reinforcers, 
international competitive reinforcers, novel material reinforcers and limited-hold contingencies, and advertising.

Reinforcers that compete against consumption skills. Consumption skills, in the sense Scitovsky discussed them, can contribute to a sustainable culture because they have the potential to improve the quality of life without a substantial draw on natural resources. Reinforcers that maintain activities incompatible with consumption skills and the free time necessary for their acquisition are therefore impediments to sustainability.

Productivity growth and associated material affluence have had the effect of making paid work more reinforcing relative to free time, creating modern freetime scarcity (Linder, 1970). This influence is even seen in education, in which increasingly narrow and specialized job training has displaced a broader liberal education that includes general intellectual and aesthetic content (Scitovsky, 1992). Time scarcity poses a serious problem for the acquisition of advanced consumption skills, which requires lots of free time (Bianchi, 2003; Linder, 1970). Learning and perfecting consumption skills, including musical and artistic competence, is also often initially stressful because task demands challenge the learner's abilities (Csikszentmihalyi, 1997; Scitovsky, 1992). Scitovsky maintained that once acquired, artistic and intellectual consumption skills produce a beneficial cascading or multiplier effect: Once acquired, additional intrinsic reinforcers are progressively forthcoming in rate and magnitude as the skills are increasingly perfected, an effect also exemplified in Csikszentmihalyi's (1990) concept of flow and in Nell's (1988) concept of ludic reading. Scitovsky's advanced consumption skills are analogous to a chained schedule of reinforcement in which the initial link has a high response requirement and a lean reinforcement rate, but the terminal link has a moderate response requirement and a rich and enduring reinforcement rate. Advanced consumption skills in part produce enduring reinforcement because they produce a continuing source of intrinsic aesthetic reinforcers. As Bianchi (2003) observed:

He [Scitovsky] also allows that there are some activities whose characteristics make them less likely to cause negative habituation. These are those creative activities that, because of their very complexity and internal variety, are able to become an endogenous source of change and novelty. (p. 403)

In Scitovsky's view, most people lack both free time and a suitable education necessary to acquire significant consumption skills, and are therefore consigned to spend their free time repeatedly doing things like watching standard TV fare, shopping, buying, and driving motor vehicles. These activities are immediately 
reinforcing and demand relatively less time than advanced consumption skills, but do not lead to further intrinsic or endogenous reinforcers. Activities such as watching TV are arguably resource-light behaviors that appear to be compatible with a sustainable use of leisure time. The problem however is that such activities are insufficiently reinforcing to produce enduring intrinsic reinforcers, and therefore fail to compete effectively with material goods for the allocation of people's time. This problem is further compounded because many people with weak consumption skills are not able to sample and compare the applicable reinforcers:

Many stimuli require for their enjoyment little or no consumption skills or skills already acquired for some other purpose; and it is natural for the unskilled consumer to seek stimulation from these. If that proves costly or yields less stimulation than he wants, he will never know it, unless by chance he later acquires some of the consumption skills he has spurned in the beginning and so can exercise retrospective rationality. (Scitovsky, 1977, p. 8)

In reconsidering Scitovsky's concerns with weak consumption skills that provide immediate reinforcers and effectively prevent the longer-term multiplier effect, Bianchi (2003) discussed the role of both hyperbolic discounting (Herrnstein, 1990) and melioration (Herrnstein \& Prelec, 1991) as two possible explanations. These phenomena may play a role in the suboptimal acquisition and reinforcement of consumption skills.

The work ethic. Several commentators have questioned various aspects of the desirability of the work ethic, a set of cultural practices aimed at boosting time allocation to work over other activities, deferring reinforcement and avoiding idleness (Beder, 2000; Kerr, 1962; Russell, 1935; Scitovsky, 1992). In his classic work Weber (1904/1958) proposed that modern capitalism owes its success to the work ethic, which he attributed in part to Calvinist beliefs that worldly material success signaled divine salvation. Kerr however traced a parallel secular source of the work ethic to the 18th Century, when utilitarian thinking (i.e., defining correct behavior as that which produces the greatest happiness for the largest number of people) became a dominant force, inducing people to consider doing things for their own sake, as occurs in many artistic activities, as less preferable than purposeful activities directed at benefiting others. (Some of Thoreau's contemporaries for example suggested that he consider working to provide for poor children, which he dismissed in part due to his valuation of aesthetic motives.) Scitovsky (1973a) similarly attributed the high value we place on work and production to the outwardly worthy motive of encouraging activities that 
benefit others and curb selfish behaviors. The problem with this ostensibly worthy and altruistic motive is that it functions unchecked in service of economic growth, diminishes aesthetic sources of pleasure and is a source of collateral emotional effects, guilt, evoked by leisure (Kerr, 1962; Scitovsky, 1992).

One component of the work ethic is the ability to defer reinforcers in time and resist the influences of immediate reinforcers, a skill that increases over the life span (Green, Fry, \& Myerson, 1994) and is correlated with various measures of general personal competence and success (Mischel, Shoda, \& Rodriguez, 1989). This skill, combined with other societal consequences that encourage work, works against the acquisition and maintenance of consumption skills that often require susceptibility to and immersion in immediate reinforcers.

Kerr (1962) took the position that the contingencies associated with utilitarian motives imprison people in a future-oriented present without pleasures:

By making usefulness in the future our single talisman, we find ourselves without a present or imprisoned in a present in which nothing real can be known-a present that is empty of everything but our despair. We go to our pleasures, when we dare to go to them at all, demanding that they surrender to us a kind of knowledge that is not in them. And so we kill them. (p. 244)

Positional reinforcers. Positional reinforcers are ones that (a) are scarce due to either natural or social conditions; and (b) are subject to change in reinforcing effectiveness due to crowding or congestion (Hirsch, 1976). Income for example is a highly positional reinforcer. An income of $\$ 10,000$ is highly reinforcing if the average income is $\$ 1000$ because the higher income is relatively scarce. Oxygen by contrast is not a positional reinforcer because it is not scarce and subject to congestion or crowding only under unusual conditions. Prestigious jobs and student admissions into top universities are positional as long as they are scarce and relatively few people have access to them. Positional reinforcers are by definition reinforcers that are scarce, but the scarcity can be due to different factors (Hirsch, 1976). Prime real estate, such as fertile cropland or waterfront properties, for example is naturally scarce due to geography. Many expensive positional reinforcers such as houses and automobiles are limited in supply because of natural limits on energy and materials. Some companies create scarcity and reinforcer positionality by manufacturing limited quantities of their product in order to elevate the selling price. Positional reinforcers can also be influenced by crowding or overuse: A residence near a park can be a positional reinforcer that can decline in value if the park becomes overused. 
Competition for positional reinforcers sets individuals against each other in a zero-sum contest in which work time and demands on natural-resource reinforcers increase (Hirsch, 1976). Although a small percentage of wealthy individuals can win the contest by collecting more positional goods than everyone else, on a collective basis society loses, both because half the population will necessarily fail to succeed in attaining average relative status (Frank, 1999, 2007; Hirsch, 1976; Schor, 1998) and because these competitive contingencies create and maintain a heavy demand for limited natural resources and contribute to overwork and overspending. In contrast nonpositional and less positional reinforcers do not create competitive pressures. As Csikszentmihalyi (1999) points out:

To be rich means that others must be poor; to be famous means that others must be anonymous; to be powerful means that others must be helpless. If everyone strives for such self-limiting rewards, most people will necessarily remain frustrated, resulting in personal unhappiness and social instability. By contrast, the rewards of flow are open-ended and inexhaustible: If I get my joy from cooking Mediterranean food, or from surfing, or from coaching Little League, this will not decrease anyone else's happiness. (p. 826)

Many positional reinforcers are valued due to a process of social comparison that results in status seeking, in which the positional reinforcer's effectiveness is due not to the usefulness of the products themselves but to the products' elevation or maintenance of the individual's position within a social hierarchy. Relatively conspicuous and expensive brand-name products often signal the user's elevated level within the positional hierarchy (Chao and Schor, 1998). People typically attribute their purchases of brand-name products to product quality rather than status-seeking, even when these attributions are dubious (Claassen, 2008). Frank (2007) maintains that positional competition for large, expensive houses, a highly conspicuous reinforcer, has created a "positional arms race" that is especially harmful to the happiness and welfare of middle class families.

Pursuit of positional reinforcers and especially status-seeking connotes individuals with superficial value systems who envy others and define themselves exclusively in economic terms. Working for positional reinforcers however does not always reflect motives we consider unworthy. People often work to purchase residences in neighborhoods with good schools because it enhances their children's future social position or status, not because they wish to be seen as superior to others. Some people work to purchase homes in areas with belowaverage schools because those areas are a step up from their even worse existing neighborhoods, in an effort to move off the bottom of the scale (Claassen, 2008) 
and gain relative safety from crime and violence. Seeking positional improvement of this type nonetheless represents the operation of the positional economy and produces its harmful aggregate effects: Positional competition pushing up from the bottom of the scale has effects throughout the hierarchy.

International competitive reinforcers. During the depression of the 1930s there was an increased openness to new ideas and this included receptivity to reduce the work week to 30 hours in order to spread the available work more widely and increase employment (Hunnicutt, 1988). Had this occurred, it would have had the potential to moderate the future level of economic activity and move the economy toward sustainability. In 1933 legislation to implement the 30-hour work week appeared on the brink of being enacted, but in the face of corporate opposition President Roosevelt effectively opposed the legislation and it was never put into law.

Later in the early 1950 s maximizing economic growth became a part of the U.S. government's cold-war strategy, as outlined in the 1950 National Security Council Report 68 (NSC-68) (National Security Council, 1950), which envisioned maintaining high levels of economic activity and full employment as a means of generating tax revenues, which in turn would augment the defense budget in order to contain the Soviet Union (Collins, 2000). The overall work week had been reduced during the entire 19th century and this continued into the early 20th century (Hunnicutt, 1988). Keynes (1930) had even envisioned an eventual 3-hour work day and a 15-hour work week for the grandchildren of his generation. With the onset of the cold war further efforts to reduce the work week became contrary to U.S. national security.

Novel material reinforcers and limited-hold reinforcement schedules. During the 19th and early 20th century work-week hours declined due in part to the effectiveness of the labor movement and the application of collective bargaining principles. Hunnicutt (1988) maintains that these reductions were consistent with Mill's perspective:

...the widespread belief in progress and human perfectibility in the nineteenth century involved the acceptance of both higher wages and shorter hours in the long term, reflecting the belief that work and even material progress were, at least in part, means to nonmaterial ends. Thus shorter hours, as a practical labor reform and political issue, figured prominently in nineteenth-century discussion about progress and the values and purposes of work and wealth. (pp. 15-16)

Beginning in the 1920 s however a new ethic called "the new economic gospel of consumption" (Hunnicutt, 1988; Kaplan, 2008) prevailed. Corporations 
had become concerned that rising material prosperity would usher in an era in which workers would become habituated with commercial products and seek more leisure time and shorter working hours, which were seen as a threat to economic growth and corporate earnings. Working hours had after all declined steadily during the 19th century. Concern with a continuation of this general trend led for example Charles Kettering (1929), a General Motors engineer and executive, to a solution: "Keep the Consumer Dissatisfied". Kettering held that it was important to make new products more reinforcing so that the consumer would be willing to sacrifice leisure time to work and consume more. The alternative to keeping the consumer dissatisfied was seen as economic stagnation:

If everyone were satisfied, no one would buy the new thing because no one would want it. The ore wouldn't be mined; timber wouldn't be cut. Almost immediately hard times would be upon us. You must accept this reasonable dissatisfaction with what you have and buy the new thing, or accept hard times. You can have your choice. (Kettering, 1929, para. 24)

Kettering's general strategy for maintaining consumption is a form of planned obsolescence. In this form the strategy is to create a series of novel products, each of which has a limited life as a fully effective reinforcer, placing consumer behavior on a limited-hold reinforcement schedule (Ferster \& Skinner, 1957). In such a schedule, behavior produces a reinforcer that is only available for consumption for a limited period of time. Limited-hold schedules produce higher rates of behavior than schedules without limited-hold requirements (Ferster \& Skinner, 1957). However, unlike reinforcers in the laboratory, older reinforcers lose their reinforcing effectiveness relative to novel reinforcers, a form of a reinforcer contrast effect (Grant \& Evans, 1994), coupled with reinforcer habituation. Packard (1960) distinguished between three forms of planned obsolescence, obsolescence of function, in which a new product is more reinforcing because it operates more effectively than an older product, obsolescence of desirability, in which the new product is more reinforcing only because it is superficially different from the well-functioning product it replaces, and obsolescence of quality, in which a shoddy product is simply designed to fail so as to ensure its repurchase. Packard called attention to the waste of natural resources in all these types of planned obsolescence.

Advertising: The commercial persuasion industry. Mass-media product advertising emerged during the early 1920s and expanded rapidly during that decade in the U.S. (Hunnicutt, 1988; Shi, 1985). It was credited with being an important force in driving increased consumption (National Bureau of Economic Research, 1929), allaying concerns expressed in the early 1920s that in order to 
create more leisure time for themselves, consumers would cut back on both their work and consumption. Today worldwide yearly advertising spending is estimated at about $\$ 450$ billion dollars (BBC, 2009). In the U.S. alone in 2007 ad spending totaled $\$ 279$ billion dollars (Galbi, 2008), then equivalent to $\$ 925$ for every American. The Food and Agricultural Organization of the United Nations (2008) has estimated the cost of completely ending world hunger at $\$ 30$ billion dollars per year, a value U.S. ad spending could pay for nine times over.

Despite these massive expenditures, U.S. consumers have an increasingly negative opinion of advertising. In a 2004 poll conducted by Yankelovich Partners, one-third of those surveyed would be willing to accept a slightly lower standard of living if they could live in a society without marketing or advertising (Greenspan, 2004). Advertising in the U.S. is a deductible business expense. In one survey $65 \%$ of respondents favored ending this tax-favored status (Schor, 1998).

Ads function through several mechanisms including Pavlovian conditioning, vicarious reinforcement, and escape conditioning. Much advertising employs Pavlovian conditioning in the form of conditioned attractions (Grant \& Evans, 1994) in which the product is differentially associated with other stimuli that already elicit positive emotional responses (e.g., Stuart, Shimp, \& Engle, 1987). Advertisers differentially associate their products with attractive nonmarket stimuli (e.g., friendships, sensuality, positive emotions, family life, social gatherings, upbeat music, and humor), imparting the deceptive message, for example, that success in personal social relationships can be achieved though product purchases (Jhally, 2002). In addition, advertising makes use of a stimuluscontrol procedures known as vicarious reinforcement (Bandura, 1969; Hawkins \& Hane, 2000), in which attractive models appear to be better off though use of the advertised product or service. High-status models make modeling more effective (Bandura, 1969) and 25\% of current ads portray a high-status celebrity, double the percentage in 1995 (Conley, 2008). Advertising also employs escape conditioning, in which a motivating operation (Michael, 2004) is used: The ad creates the impression that people who do not have or use the product are personally inadequate or lacking, a state that can be escaped only through regular product purchase and use. Richins (1991) found that advertising using attractive models initiates a process of social comparison that induces consumers to rate normal people as less attractive and to feel less satisfied with their own appearance. Advertisements have appeared in increasingly more subtle and pervasive forms, as illustrated by product placement methods in which attractive movie stars playing heroic roles use branded products in films, including dangerous products like cigarettes that are banned from conventional ads in many 
countries. Engels, Hermans, van Baaren, Hollenstein and Bot (2009) found that viewing televised movie or ad models who drank substantial alcohol caused the viewers to increase their consumption of alcohol when given the opportunity.

Ads induce people to consume inessential products and unnecessarily increase the use of natural resource reinforcers, but people falsely believe that as long as they are aware that advertisers are attempting to influence them they can control the extent of that influence (Wilson, 2002). People use introspection, a faulty method of assessing actual influence, to conclude that ads do not influence them significantly. This dismissal of advertising's influence in turn has the insidious result of increasing advertising's effectiveness because people are caught off guard (Wilson, 2002).

From the perspective of behavior analysis, the operation of conditioning in day-to-day life is ubiquitous rather than something to be regarded as necessarily menacing. What makes advertising so dangerous and powerful as a form of behavior control is that it is relentlessly concentrated on producing only one type of behavior, consumption, at the exclusion of all else. Sneddon (2001) considers this concentration of influence a moral problem because it "works against the willingness of people to examine their lives against a rich background of values and possibilities" (p. 23). With many daily conditioning trials, this has contributed to development of a culture in which people neglect nonmarket reinforcers (Waide, 2001) and even go so far as to develop a sense of trivialized personal identity based on the products they use rather than based on more substantial and important human values (Cushman, 1990; Fromm, 1976; Jhally, 2002; Walker, 2008).

\section{Opportunities for Sustainability}

Successful implementation of a steady-state economy requires a constant rate of throughput such that a uniform rate of natural-resource reinforcement maintains a steady-state of economic behavior. The major general challenge to such an implementation is to change the basic pattern of the existing economic system, in which a growing supply of inessential consumer goods reinforces more labor from more workers to pay for these products. Because economic growth has such a well-fortified position, any ultimately successful attempt to move from a growth economy to steady-state economy is likely to occur only incrementally. Relatively little is known about how to manage a successful transition from a growth economy to a steady-state economy because of the lack of historical precedents. Experimentation with small scale pilot projects would be useful in identifying effective transition strategies. 
From among a large number of potential steps toward a steady-state economy, only a select few are briefly discussed here: Goal setting, government policies, countering advertising, reducing work time, adopting voluntary simplicity, adopting Bohemianism and other alternative positional reinforcement systems, and education.

\section{Goal Setting}

Setting goals and identifying target behaviors is a basic feature of behavioral interventions that has been shown to be useful in a variety of settings (Locke, Shaw, Saari, \& Latham, 1981; Mento, Steele, \& Karen, 1987), especially when combined with ongoing feedback concerning whether the goals are being met (Erez, 1977; Reber \& Wallin, 1984). Goal setting is however only helpful if the appropriate goals are being set. The issue of selecting the appropriate behavioral targets has been an extensive area of work, often discussed under the rubric of social validity (Wolf, 1978). Developed economies have measured their progress using indices of economic activity such as gross domestic product (GDP) as an index of economic strength and health. One problem with GDP as a measure is that it encompasses all economic activity including spending on undesirable events such as automobile accidents, hurricanes, treating fatal diseases, etc., all of which boost GDP but do not have a net positive effect on personal well-being (Cobb, Goodman, \& Wackernagel, 1999). Use of GDP also defines progress in terms of economic growth, which is not sustainable. These difficulties with GDP have been addressed through the development of alternative indices of well-being composed of measures broader than mere aggregate economic activity. For example the Genuine Progress Indicator (GPI) (Anielski, 2007) was developed to measure changes in the quality of life. It uses traditional indices such as GDP, but also taps a wide variety of other indicators including self-rated happiness, life expectancy, leisure time, strength of personal relationships, personal indebtedness, foreign indebtedness, poverty rates, youth suicide, violence in society, income and wealth inequality, and environmental health. The GPI was developed in part to take issues of sustainability into account.

Whereas U.S. GDP rose by 64\% from 1980 to 1998, GPI declined during this time by over 10\% (Cobb et al. 1999), a pattern seen in other independent studies (Anielski, 2007). One rationale for maintaining economic growth is that it makes people better off, but during 1980 to 1998, when the GDP grew strongly, the GPI showed that people were left worse off. These data indicate that GDP should be largely abandoned as an index of societal progress and be replaced with the GPIlike indicator that measures well-being and sustainability. Continued use of GDP 
to assess progress is analogous to a behavior-analysis intervention in which a target behavior lacks social validity.

Replacement of GDP with GPI-like indicators may be one of the more relatively achievable opportunities in building a sustainable culture. French President Nicolas Sarkozy, known as a political conservative, has established a commission to study measuring the well-being of the population using a broader range of statistics (Wordsworth, 2009).

\section{Government Policies}

One solution to reducing resource-intensive consumption is to tax it, which would encourage people to allocate their time away from overconsumed reinforcers in favor of toward underconsumed reinforcers. As a means of addressing the problems of overconsumption, Frank (1999) proposed a progressive consumption tax as a replacement for income taxes. Under this plan, everyone would receive a standard per-person deduction that would be exempt from taxation. This standard deduction would shield low-income earners, who cannot afford to save anything, from a consumption tax. Savings, defined as money contributed to a special (IRA-like) account, would not be taxed. Consumption, defined as the remainder of income minus savings and taxes, would be taxed, with an increasing percentage of tax levied on progressively higher levels of consumption. This incentive system would still make it possible for people to engage in competitive status-seeking through consumption, but doing so would invoke tax penalties, with taxes increasing with rising consumption.

Government policies that provide good schools, parks, recreational facilities, health care and other services are all helpful in mitigating the harmful effects of positional and status reinforcers by lessening their influence. Galbraith's (1998) concerns regarding the effects of a society of private affluence and public squalor have renewed ecological importance because of the harmful effects of positional reinforcers on sustainability. Turning desirable waterfront property into public park lands, for example, makes reinforcing activities more widely available and allows people to share, rather than compete for scarce resources. Providing good schools for all students reduces competition for housing in good neighborhoods (Sanne, 2002), as does allowing students to cross geographical boundaries to attend good schools and establishing affordable public universities (Warren \& Tyagi, 2003). 


\section{Countering Advertising}

Product advertising can be countered in a variety of ways. Two options considered here are prohibiting advertising and promoting reverse advertising.

Prohibiting unsustainable products. In Walden Two, radio programs were rebroadcast into the community with the advertisements removed. Even in our society advertising has come to be increasingly regulated and prohibited due to the dangers of advertised products. Tobacco and alcohol advertising, once accepted as normal, is either banned or restricted in many countries. If sufficiently comprehensive, bans on alcohol and tobacco ads do reduce the use of these products (Saffer \& Chaloupka, 2000; Saffer \& Dhaval, 2006). As awareness of the dangers of all unnecessary resource-intensive consumption grows, more advertised products can be subject to restrictions. Monbiot (2009) for example has called on newspapers to cease accepting advertising from auto dealers and airlines because what they sell is so harmfully resource-intensive.

Reverse advertising. Outright bans on advertising may be only gradually successful in Western democracies due to strong historical protection of freedom of expression. One option is to require public media to provide public-service anticonsumption ads or ads promoting sustainable time-use alternatives to material consumption. Anticonsumption campaigns against cigarette smoking have been shown to be effective (Pechmann \& Shih, 1999; Wakefield, Flay, Nichter, \& Giovino, 2003), suggesting their application to address problems of sustainability.

There are currently public-service advertisements for both curtailing consumption and for promoting the consumption of underconsumed reinforcers. An organization called Adbusters (Adbusters, 2009; Bordwell, 2002), through its Media Carta campaign, has conducted anticonsumption advertising, making television ads to promote "Buy Nothing Day" and to diminish the reinforcing effectiveness of specific brand-name products. Most TV networks have refused to broadcast these ads. Adbusters is currently pursuing these refusals in the Canadian court system in order to allow private citizens and noncommercial interests the right to make use of the public airwaves in the same way that corporations do. The Mormon church has also produced television and radio advertisements (Mormon.org, 2009) that seek to increase the reinforcing effectiveness of family activities, desirable time-use alternatives to material consumption.

\section{Reducing Work Time}

Reducing the amount of time spent working for disposable income is sometimes seen as a extreme proposal, but such a development would simply be a 
reinstatement of the trend of the entire 19th and early 20th centuries (Hayden, 1999), before what Hunnicutt (1988) refers to as "the gospel of consumption" became so well established. Work time reductions would lessen resource depletion, provide free time that could be used to acquire consumption skills, enhance social capital, allow for the creative use of leisure time, and fulfill the promise of a participatory democracy by giving workers time to be actively involved in political processes (Hayden, 1999; Reid, 1995). Hunnicutt (1992, 1996) identified many of these benefits in his examination of the effects of the Kellogg cereal company's adoption of a 6-hour workday in 1930.

There are practical, though resolvable problems in implementing work time reductions (de Graaf, 2003; Hayden, 1999). For example, one impediment to reducing working hours is that employment in industrialized countries is mainly offered on a full-time 40-hour/week basis or not at all (Sanne, 2002). Although part-time jobs are available, they are lower paying, have fewer opportunities for advancement and provide less heath-care and pension benefits than full-time jobs. Part-time workers are $87 \%$ less likely to receive health insurance or pension benefits (Wenger, 2001). In addition, many government social-insurance (social security) and unemployment insurance programs provide benefits only to fulltime employees (Shulman, 2008). Working 40 hours per week or more is therefore differentially reinforced.

The problem of offering jobs at full-time or not at all could be addressed by enacting legislation that gives prospective employees the right to accept jobs on, for example a three-quarters or half-time basis and gives existing employees the right to reduce their work time by one-quarter or one-half, both conditions subject to only prorated reductions in benefits. In developed economies that have considerable discretionary spending, allowing people to work less than the standard full-time work arrangements would help to slow the unsustainable cycle in which people use natural resources in their work to pay for products that are themselves resource-intensive. [See Hayden (1999) for a treatment of this and other practical issues involved in implementing work time reductions.]

\section{Adopting Voluntary Simplicity}

How and why underconsumed reinforcers gain influence over overconsumed ones is not well understood, but a useful starting point is understanding the behavior of voluntary simplifiers. Voluntary simplifiers are people who spend money on only essentials and have otherwise altered their lifestyle so as to work less, consume less, and yet improve the quality of their lives. Pierce (2003b) states: 


\section{GRANT}

Proponents of simplicity as a way of life reject the notion that our life goal should be to amass as much material wealth and prestigious accomplishments as we possibly can. Their lifestyles tend to involve patterns of working less, wanting less and spending less. (para. 2)

Yet, the focus of simplifiers is not to avoid material consumption but to progress beyond it:

Simplicity can best be achieved by paring your life down to its essentials--those things, activities and relationships you either truly need or genuinely cherish. Simplicity involves unburdening your life, and living more lightly with fewer distractions that interfere with a high quality life, as defined uniquely by each individual. (Pierce, 2003b) (para. 3)

Voluntary simplifiers are important because their behavior is already largely consistent with a sustainable society and they have achieved this without the application of systematic external contingencies, prodding by government policies, etc. For this reason simplifiers can serve as a role model group for use in studies using the social comparison method of social validity (Kazdin, 1977). Voluntary simplifiers are also of interest because many of them are not centrally motivated by purely ideological concerns with sustainability, the environment (Schor, 1998), or excess corporate power (Huneke, 2005). In her study Pierce (2003a) found that more than half of her sample of voluntary simplifiers had little or only moderate concern with the Earth and its resources. These findings suggest that many adopt voluntary simplicity practices not as a form of ideological selfdenial, but as a means of maximizing reinforcers other than those popular in consumer culture.

Voluntary simplifiers take a pragmatic approach to work, finances, and to providing for basic day-to-day reinforcers (Dominguez \& Robin, 1992; Etzioni, 1998). This pragmatism, which stands in sharp contrast to the waywardness of both early 20th century Bohemians (Nicholson, 2002) and the 1960s counterculture (Skinner, 1978), may serve to help make voluntary simplicity sustainable as a cultural alternative to consumerism: Voluntary simplicity has already endured since the early 1980s (Elgin, 1993) and continues to grow (Maniates, 2002). 


\section{Adopting Bohemianism and Other Alternative Positional Reinforcement Systems}

As described earlier positional reinforcers based on income, wealth, and material possessions pose a difficult problem in achieving a sustainable culture because once even a substantial minority the population is in competition for these reinforcers work hours, consumption, and the draw on natural resource reinforcers rises. Possible solutions are to infuse mainstream culture with alternative values such as the artistic values of Bohemian communities (de Botton, 2004) or to create a separate Bohemian community. Various forms of the performing, visual and literary arts have thrived since ancient times, attesting to both their appeal and independence from modern industrial and consumer culture.

In Walden Two, Skinner (1976, Chapter 11) described a society in which people pursued aesthetic reinforcers instead of material affluence, creating a Golden Age in the arts. This artistic focus in Walden Two, coupled with its rejection of conventional economic materialism, qualify it as a Bohemian community and as a model for a cultural Renaissance (cf., Shafer, 2008). Walden Two's Bohemianism is often overlooked due to its explicit design, its brevity of the depiction of artistic life, its fleeting references to experimental art forms that are characteristic of Bohemian communities (Stover, 2004; Wetzsteon, 2002), and the community's pragmatic approach to providing for food, shelter, and clothing. The community's attention to providing for necessities, something it shares with modern voluntary simplifiers, offers a model for a practical and therefore enduring populist Bohemian culture.

As de Botton (2004) has acknowledged, positional reinforcers operate in Bohemian communities, but position is conferred by artistic and intellectual talent and skill; positional placement by money or material possessions is actively repudiated. Skill-based positionality within Bohemian subcultures can itself be a concern. For example, the emergence of competitiveness and skill-based positional reinforcement among Walden Two's singers was forestalled through "a special bit of cultural engineering" (Skinner, 1976, p. 82). Whatever relatively minor adverse effects skill-based positional reinforcers may have, they encourage competition for underconsumed reinforcers, displacing time spent competing for natural-resource reinforcers, and therefore promote sustainability.

Bohemian values, along with philosophical and religious perspectives that embrace voluntary poverty, are the most diametric challenges to consumerism because they explicitly reject material values. Other alternative value systems that compete with the positional economy also exist, but are less explicitly anticonsumeristic or antimaterialistic. To take only a few examples, open-source 
computer communities, amateur sports and fitness subcultures, bridge players, conversationalists, and individuals pursuing various hobbies are often avidly motivated by conceptions of success and failure distinct from those of consumerism. However, because many of these activities do not explicitly shun consumer culture, they are more apt to be co-opted by that culture, as for example seen in the way many types of athletics have been professionalized and otherwise overwhelmed by financial interests (e.g., Zimbalist, 1999). Each of these activities is nonetheless valuable because it provides a means of defining success and failure in a way that departs from the consumer culture's unitary focus on wealth and possessions. Further, the more of these alternative value systems that are available, the more likely any one individual is to have a means of finding personal reinforcers that are compatible with sustainability. However, because of the power and behavioral momentum of consumerism, Bohemian culture is likely to be at least transitionally important in any even partial displacement of consumer culture due to both its steadfast repudiation of consumerism and the multiplier effect the arts have in generating an enduring sources of intrinsic reinforcement.

\section{Education}

Beyond simply using education to establish greater awareness of sustainability issues is an imperative to shift the maintenance of behavior from overconsumed to underconsumed reinforcers by teaching consumption skills. The consumption skills implicit in Mill's art of living, in Walden Two's Golden Age, and in Scitovsky's prescription for cultural invigoration are all acquired tastes established as reinforcers only through informal or formal educational experiences. The recognition that the arts are a potential means of furthering sustainability dramatically reframes educational and other public-policy priorities. As Scitovsky (1989b) points out:

... the argument just presented favours subsidies, not to the arts or access to the arts, but to the process of learning to enjoy them. Such subsidies therefore should be immune to the criticism often leveled at public support for the arts on the ground that it represents a regressive redistribution of income from taxpayers to the elite that forms the bulk of theatre, opera and concert audiences. For the purpose of art education is to increase and keep increasing membership in that elite until it ceases to be an elite. (p. 157) 
To further arts education, Scitovsky (1992) advocated a broad education throughout the curriculum that encompasses arts instruction. His promotion of arts education is based in part on avoiding the harmful effects (i.e., negative externalities) of alternative reward-seeking behaviors, which include crime, violence and drug use, in addition to squandering natural resources (Scitovsky, 1977; 1992). He cited the teaching of arts in kindergarten and the elementary grades as an exemplary practice because only there students are given freedom to pursue aesthetic challenges and pleasures independently of vocational considerations. He further suggested that existing practices in promoting athletics in schools are "a fine example that cultural education easily could and ideally ought to follow" (p. 301). Scitovsky (1992) envisioned formal arts education as an important supplement to domestic life, pointing out that children acquire an enjoyment of literature and music relatively effortlessly when grow up in literary and musical families. Under no illusions of the difficulties in making a transition to an arts-centered society, Scitovsky (1989b) anticipated that the process would "be a matter of generations rather than of years" (p. 158).

The connection between sustainability and arts education has important implications for behavioral interventions. Programs to teach aesthetic and other consumption skills should be clearly recognized as green interventions alongside those (e.g., bike riding, recycling, etc.) that are traditionally associated with sustainability and are in certain respects preferable to energy-efficiency interventions, which are potentially compromised by longer-term Jevons effects. Consumption-skill interventions address core issues of time allocation to resource-free and resource-light activities. Such interventions have the potential to produce enduring behavior changes though contact with natural reinforcers (Ferster, 1967) and natural maintaining contingencies (Stokes \& Baer, 1977).

There is a tendency in the developed world to turn to historically successful scientific technologies to solve problems, an impulse that often leads only to improvements in energy efficiency. Purchases of hybrid cars and development of expansive wind and solar infrastructure projects, for example, are reassuring to many in part because they provide concrete visible evidence that we are addressing problems of sustainability. Yet, these salient interventions are by themselves severely limited due to Jevons effects unless paired with broader changes in lifestyle. Behavioral and cultural solutions, especially those focused on consumption skills, arts education, and movement toward an aesthetically based culture initially seem counterintuitive, irrelevant and insubstantial when juxtaposed with the powerful technologies science and engineering have to offer. This perception, seen even among those sympathetic to issues of sustainability, represents the persistence of the material values that have precipitated a crisis in 
sustainability. Behavioral, cultural and aesthetic solutions can, in contrast, alter the fundamental motivation to seek material rewards and solutions, break the cycle of work-to-consume and achieve genuine progress toward sustainability.

\section{Summary}

As Mill recognized in his time, it is ultimately necessary for economic growth to cease and the economy to enter an era in which a stable rate of natural resource use reinforces a steady state of human economic behavior. As Hubbert foresaw it, our ability to make this transition, from a growth economy to a steadystate economy, is the key challenge of our time. The worst danger is reaching a state of overshoot, in which the human population grows too large to support itself at a time when growth of natural resources collapses rapidly. Avoiding such a calamity is a behavioral process, so understanding the specific behavioral variables and processes underlying this process should also become a key challenge of our era. As discussed here, time lines are difficult to fix but signs of problems in resource supply have already appeared just at a time when growth in many industrializing economies is accelerating.

Mill also recognized that the end of the age of growth held considerable promise. A cultivated mind, like a patient understudy waiting in the wings during centuries of material prosperity, would one day have a chance to take center stage as economic growth went into a terminal decline. Acquisition of consumption skills allows us to tap enduring sources of intellectual and aesthetic challenges and pleasures that require relatively little in the way of material wealth. This promising yet largely dormant notion has appeared sporadically, sometimes even with flashes of prominence, during two centuries of expanding material wealth, culminating in the consumerism of the late 20th and early 21 st centuries. Even in the absence of any organized movement, individuals have taken upon themselves to adopt lifestyles of voluntary simplicity, intuitively seeking a superior alternative to lives of work-to-consume. Alternative Bohemian, counterculture, and subculture communities, despite their faults, have always kept alive alternative value systems that prize such things as aesthetic achievements over accumulation of positional reinforcers. Skinner's Utopian vision of a postconsumer society continues to offer a glimpse of a viable culture that addresses the practical problems of Bohemianism while retaining the allure of an alternative aesthetically-based value system. 


\section{SUSTAINABILITY: FROM EXCESS TO AESTHETICS}

\section{References}

Adbusters. (2009). Adbusters culturejammer headquarters: Journal of the Mental Environment. Retrieved from https://www.adbusters.org/.

Ainslie, G. (2001). Breakdown of will. Cambridge, U.K.: Cambridge University Press.

Altus, D. E., \& Morris, E. K. (2004). B. F. Skinner's utopian vision: Behind and beyond Walden Two. Contemporary Justice Review, 7, 267-286. http://dx.doi.org/10.1080/1028258042000266004

Anielski, M. (2007). The economics of happiness: Building genuine wealth. Gabriola Island, British Columbia, Canada: New Society Publishers.

Bandura, A. (1969). Principles of behavior modification. New York: Holt, Rinehart \& Winston.

Bardi, U. (2008). The universal mining machine. Retrieved from http://europe.theoildrum.com/node/3451.

Bardi, U., \& Pagani, M. (2007). Peak minerals. Retrieved from http://europe.theoildrum.com/node/3086.

BBC. (2009). Bleak prediction for advertising. Retrieved from http://news.bbc.co.uk/2/hi/business/7998010.stm.

Beder, S. (2000). Selling the work ethic: From Puritan pulpit to corporate PR. New York: Zed.

Bianchi, M. (2003). A questioning economist: Tibor Scitovsky's attempt to bring joy into economics. Journal of Economic Psychology, 24, 391-407. http://dx.doi.org/10.1016/S0167-4870(03)00019-9

Bordwell, M. (2002). Jamming culture: Adbusters' hip media campaign against consumerism. In T. Princen,, M. Maniates \& K. Conca (Eds.), Confronting consumption (pp. 237-253). Cambridge, MA: MIT Press.

Brenno, J. (2009). Hubbert's early take on nuclear energy. Retrieved from http://channelinghubbert.com/2009/03/08/hubberts-early-take-on-nuclear-energy/.

Brown, L. R. (2004). Outgrowing the Earth: The food security challenge in an age of falling water tables and rising temperatures. New York: W. W. Norton.

Catania, A. C. (1998). Learning (4 ${ }^{\text {th }}$ ed.). Upper Saddle River, NJ: Prentice-Hall.

Catton, W. (1982). Overshoot: The ecological basis of revolutionary change. Urbana, IL: University of Illinois Press.

Chao, A., \& Schor, J. B. (1998). Empirical tests of status consumption: Evidence from women's cosmetics. Journal of Economic Psychology, 19, 107-131. http://dx.doi.org/10.1016/S0167-4870(97)00038-X

Claassen, R. (2008). The status struggle: A recognition-based interpretation of the positional economy. Philosophy and Social Criticism, 34, 1021-1049. http://dx.doi.org/10.1177/0191453708096965

Cobb, C., Goodman, G., Wackernagel, M. (1999). Why bigger isn't better: the genuine progress indicator - 1999 update. San Francisco: Redefining Progress.

Collins, R. M. (2000). More: The politics of economic growth in postwar America. Oxford: Oxford University Press.

Conley, L. (2008). Obsessive branding disorder: The illusion of business and the business of illusion. New York: Public Affairs.

Cooper, J. O., Heron, T. E., \& Heward, W. L. (2007). Applied Behavior Analysis (2nd ed.) Upper Saddle River NJ: Pearson Prentice Hall.

Csikszentmihalyi, M. (1990). Flow: The psychology of optimal experience. New York: Harper \& Row.

Csikszentmihalyi, M. (1997). Finding flow. New York: Basic Books.

Csikszentmihalyi, M. (1999). If we are so rich, why aren't we happy? American Psychologist, 54, 


\section{GRANT}

821-827. http://dx.doi.org/10.1037/0003-066X.54.10.821

Cushman, P. (1990). Why the self is empty: Toward a historically situated psychology. American Psychologist, 45, 599-611. http://dx.doi.org/10.1037/0003-066X.45.5.599

Daly, H. E. (1991). Steady-state economics (2nd ed.). Washington DC: Island Press.

Daly, H. E. (1996). Beyond growth: The economics of sustainable development. Boston: Beacon.

Daly, H. E., \& Cobb, J. B. Jr. (1994). For the common good: Redirecting the economy toward community, the environment, and a sustainable future. (2nd. ed.). Boston: Beacon.

Daly, H. E., \& Farley, J. (2004). Ecological economics: Principles and applications. Washington DC: Island Press.

de Botton, A. (2004). Status anxiety. New York: Pantheon.

de Graaf, J. (Ed.) (2003). Take back your time: Fighting overwork and time poverty in America. San Francisco: Berrett-Koehler.

Deffeyes, K. S. (2005). Beyond oil: The view from Hubbert's peak. New York: Farrar, Straus and Giroux.

Deffeyes, K. S. (2006). Join us as we watch the crisis unfolding. Retrieved from http://www.princeton.edu/hubbert/current-events-06-02.html.

Diamond, J. M. (2005). Collapse: How societies choose to fail or succeed. New York: Viking.

Dominguez, J., \& Robin, V. (1992). Your money or your life: Transforming your relationship with money and achieving financial independence. New York: Penguin.

Elgin, D. (1993). Voluntary simplicity: Toward a way of life that is outwardly simple, inwardly rich (rev. ed.). New York: Morrow.

Engels R. C., Hermans R., van Baaren R. B., Hollenstein T., \& Bot S. M. (2009). Alcohol portrayal on television affects actual drinking behaviour. Alcohol and Alcoholism, 44, 244249. http://dx.doi.org/10.1093/alcalc/agp003

Epstein, R. (1993). Generativity theory and education. Educational Technology, 33(10), 40-45.

Erez, M. (1977). Feedback: A necessary condition for the goal setting - performance relationship. Journal of Applied Psychology, 62, 624-627.

Etzioni, A. (1998). Voluntary simplicity: Characterization, select psychological implications, and societal consequences. Journal of Economic Psychology, 19, 619-643.

Evans, R. I. (1981). Dialogue with B. F. Skinner. New York: Prager.

Ewing, B. S., Goldfinger, M., Wackernagel, M., Stechbart, M., Rizk, S. M., Reed, A., \& Kitzes, J. (2008). The ecological footprint atlas 2008. Oakland, CA: Global Footprint Network. Retrieved from http://www.footprintnetwork.org/download.php?id=506.

Farzad, R. (2008). The oracle of oil speaks: Charles Maxwell, the world's wisest energy analyst, says the crunch will only get worse. Retrieved from http://www.businessweek.com/magazine/content/08_27/b4091075505012.htm.

Ferster, C. B. (1967). Arbitrary and natural reinforcement. The Psychological Record, 17, 341349.

Ferster, C. B., \& Skinner, B. F. (1957). Schedules of reinforcement. New York: Appleton-CenturyCrofts.

Food and Agricultural Organization of the United Nations. (2008). The world only needs 30 billion dollars a year to eradicate the scourge of hunger. Retrieved from http://www.fao.org/Newsroom/en/news/2008/1000853/index.html.

Frank, R. H. (1999). Luxury fever: Money and happiness in an era of excess. Princeton, NJ: Princeton University Press.

Frank, R. H. (2007). Falling behind: How rising inequality harms the middle class. Berkeley, CA: University of California Press. 


\section{SUSTAINABILITY: FROM EXCESS TO AESTHETICS}

Fromm, E. (1976). To have or to be. New York : Continuum.

Galbi, D. (2008). U.S. annual advertising spending since 1919. Retrieved from http://www.galbithink.org/ad-spending.htm.

Galbraith, J. K. (1998). The affluent society (40th Anniversary edition). New York: Houghton Mifflin.

Galor, O., \& Weil, D. N. (1999). From Malthusian stagnation to modern growth. The American Economic Review, 89, 150-154. http://dx.doi.org/10.1257/aer.89.2.150

Geller, E. S. (1992). It takes more than information to save energy. American Psychologist, 47, 814-815. http://dx.doi.org/10.1037/0003-066X.47.6.814

Geller, E. S., Winett, R. A., \& Everett, P. B. (1982). Preserving the environment: New strategies for behavior change. New York: Pergamon Press.

Gilbert, R., \& Perl, A. (2008). Transport revolutions: Moving people and freight without oil. Stirling, VA: Earthscan.

Glenn, S. S. (1991). Contingencies and metacontingencies: Relations among behavior, cultural, and biological evolution. In P. A. Lamal (Ed.), Behavioral analysis of societies and cultural practices (pp. 39-73). New York: Hemisphere Publishing.

Glenn, S. S., \& Malott, M. E. (2004). Complexity and selection: Implications for organizational change. Behavior and Social Issues, 13, 89-106.

Grant, L. K. (2005). The secrets of Scheherazade: Toward a functional analysis of imaginative literature. The Analysis of Verbal Behavior, 21, 181-190.

Grant, L. K. (2007). Peak oil as a behavioral problem. Behavior and Social Issues, 16, 65-88. http://dx.doi.org/10.5210/bsi.v16i1.405

Grant, L. K., \& Evans, A. N. (1994). Principles of behavior analysis. New York: Harper Collins.

Green, L., Fry, A. F., \& Myerson, J. (1994). Discounting of delayed rewards: A life-span comparison. Psychological Science, 5, 33-36. http://dx.doi.org/10.1111/j.1467-9280.1994.tb00610.x

Greenspan, R. (2004). Consumers becoming market resistant. Retrieved from http://www.clickz.com/3344701.

Halweil, B., Mastny, L., Assadourian, E., Flavin, C., French, H., Gardner, G., Nierenberg, D., Postel, S., Renner, M., Sarin, R., Sawin, J., Vickers, A., Starke, L., \& The Worldwatch Institute. (2004). State of the world 2004. New York: W. W. Norton.

Hansen, J., Sato, M., Kharecha, P., Beerling, D., Berner, R., Masson-Delmotte, V., ...Zachos, J. C. (2008). Target atmospheric CO2: Where should humanity aim? The Open Atmospheric Science Journal, 2, 217-231. http://dx.doi.org/10.2174/1874282300802010217

Hardin, G. (1993). Living within limits: Ecology, economics and population taboos. New York: Oxford University Press.

Hawken, P., Lovins, A., \& Lovins. L. H. (1999). Natural capitalism: Creating the next industrial revolution. Boston: Little Brown.

Hawkins, K., \& Hane, A. (2000). Adolescents' perceptions of print cigarette advertising: A case for counteradvertising. Journal of Health Communication, 5, 83-96. http://dx.doi.org/10.1080/108107300126786

Hayden, A. (1999). Sharing the work, sparing the planet: Work time, consumption, \& ecology. Toronto, Canada: Between the Lines.

Herrnstein, R. J. (1990). Rational choice theory: Necessary but not sufficient. American Psychologist, 45, 356-367. http://dx.doi.org/10.1037/0003-066X.45.3.356

Herrnstein, R. J., \& Prelec, D. (1991). Melioration: A theory of distributed choice. Journal of Economic Perspectives, 5, 137-156. http://dx.doi.org/10.1257/jep.5.3.137

Hirsch, F. (1976). Social limits to growth. Cambridge, MA: Harvard University Press.

Hirsch, R. L., Bezdek, R., \& Wendling, R. (2005). Peaking of world oil production: Impacts, mitigation, \& risk management. Retrieved from 


\section{GRANT}

http://www.netl.doe.gov/publications/others/pdf/Oil_Peaking_NETL.pdf.

Hubbert, M.K. (1956, March). Nuclear energy and the fossil fuels. Paper presented at the spring meeting of the Southern District, American Petroleum Institute, San Antonio, TX. Retrieved from http://www.hubbertpeak.com/Hubbert/1956/1956.pdf.

Hubbert, M. K. (1981). The world's evolving energy system. American Journal of Physics, 49, 1007-1029. http://dx.doi.org/10.1119/1.12656

Huneke, M. (2005). The face of the un-consumer: An empirical examination of the practice of voluntary simplicity in the United States. Psychology \& Marketing, 22, 527-550.

Hunnicutt, B. K. (1988). Work without end: Abandoning shorter hours for the right to work. Philadelphia: Temple University Press.

Hunnicutt, B. K. (1992). Kellogg's six-hour day: A capitalist vision of liberation through managed work reduction. Business History Review, 66, 475-522.

Hunnicutt, B. K. (1996). Kellogg's six-hour day. Philadelphia: Temple University Press.

Intergovenmental Panel on Climate Change. (2007). Climate change 2007. The physical science basis. Retrieved from

http://www.ipcc.ch/publications_and_data/publications_ipcc_fourth_assessment_report_wg1_ report_the_physical_science_basis.htm.

Jevons, W. S. (1866). The coal question. Retrieved from http://www.econlib.org/library/YPDBooks/Jevons/jvnCQCover.html.

Jhally, S. (2002). Advertising \& the end of the world [Motion Picture]. Northhampton, MA: Media Education Foundation.

Kaplan, J. (2008). The gospel of consumption and the better future we left behind. Orion Magazine. Retrieved from http://www.orionmagazine.org/index.php/articles/article/2962.

Kaza, S. (2000). Overcoming the grip of consumerism. Buddhist-Christian Studies, 20, 23-42. http://dx.doi.org/10.1353/bcs.2000.0013

Kaza, S. (Ed.). (2005). Hooked! Buddhist writings on greed, desire, and the urge to consume. Boston: Shambhala.

Kazdin A. E. (1977). Assessing the clinical or applied importance of behavior change through social validation. Behavior Modification, 1, 427-452. http://dx.doi.org/10.1177/014544557714001

Kerr, W. (1962). The decline of pleasure. New York: Simon and Schuster.

Kettering, C. F. (1929). Keep the consumer dissatisfied. Retrieved from http://www.wwnorton.com/college/history/archive/resources/documents/ch27_02.htm.

Keynes, J. M. (1930). Economic possibilities for our grandchildren. Retrieved from www.econ.yale.edu/smith/econ116a/keynes 1.pdf.

Knelman, F. H. (1999). Y2K and accidental nuclear war. Peace Magazine. 15, 18(May-June). Retrieved from http://archive.peacemagazine.org/v15n3p18.htm.

Koger, S. M., \& Winter, D. D. (2010). The psychology of environmental problems (3rd ed.). New York: Taylor \& Francis.

Krugman, P. (2009). The Malthusian insult. Retrieved from http://krugman.blogs.nytimes.com/2009/07/01/the-malthusian-insult/.

Kunstler, J. H. (2005). The long emergency: Surviving the converging catastrophes of the twentyfirst century. New York: Atlantic Monthly Press.

Laherrère, J. (2007). Interview with Jean Laherrère. Retrieved from http://www.hubbertpeak.com/laherrere/TheOilDrum_Interview_JeanLaherr\%C3\%A8re.pdf.

Lalli, J. S., Zanolli, K., \& Wohn, T. (1994). Using extinction to promote response variability. Journal of Applied Behavior Analysis, 27, 735-736. http://dx.doi.org/10.1901/jaba.1994.27-735

Leggett, J. (2005). The empty tank: Oil, gas, hot air, and the coming global financial catastrophe. New York: Random House. 


\section{SUSTAINABILITY: FROM EXCESS TO AESTHETICS}

Linder, S. B. (1970). The harried leisure class. New York: Columbia University Press.

Locke, E. A., Shaw, K. N., Saari, L. M., \& Satham, G. P. (1981). Goal setting and task performance: 1969-1980. Psychological Bulletin, 90, 125-152. http://dx.doi.org/10.1037/0033-2909.90.1.125

Maibach, E., Roser-Renouf, C., \& Leiserowitz, A. (2010). Global warming's six Americas, January 2010: An audience segmentation analysis. New Haven, CT: Yale Project on Climate Change. Retrieved from http://environment.yale.edu/uploads/SixAmericasJan2010.pdf.

Malott, R. W. (1986). Self-management, rule-governed behavior, and everyday life. In H. Reese \& L. J. Parrott (Eds.) Behavior science: Philosophical, methodological, and empirical advances (pp. 207-228). Hillsdale, NJ: Lawrence Erlbaum.

Malthus, T. (1798/1998). An essay on the principle of population. Amherst, NY: Prometheus.

Maniates, M. (2002). In search of consumptive resistance: The voluntary simplicity movement. In T. Princen,, M. Maniates \& K. Conca (Eds.), Confronting consumption (pp. 199-235). Cambridge, MA: MIT Press.

Martin, G., \& Pear J. (2003). Behavior modification: What it is and how to do it. ( $7^{\text {th }}$ edition). Upper Saddle River, NJ: Prentice-Hall.

McBride, T. (1997). Frugal luxuries: Simple pleasures to enhance your life and comfort your soul. New York: Bantam.

McDonough, W. and Braungart, M. (2002). Cradle to cradle: Remaking the way we make things. New York: North Point Press.

McKibben, B. (2007). Deep economy: The wealth of communities and the durable future. New York: Times Books.

Meadows, D., Randers, J., \& Meadows, D. (2004). Limits to growth: The 30-year update. White River Junction, VT: Chelsea Green.

Mento, A. J., Steel, R. P., \& Karen, R. J. (1987). A meta-analytic study of the effects of goal setting on task performance: 1966-1984. Organizational Behavior and Human Decision Processes, 39, 52-83. http://dx.doi.org/10.1016/0749-5978(87)90045-8

Michael, J. (2004). Concepts and principles of behavior analysis. Kalamazoo, MI: Association for Behavior Analysis.

Mill, J. S. (1879/2004). Utilitarianism. Retrieved from http://www.gutenberg.org/files/11224/11224-h/11224-h.htm.

Mill, J. S. (1909/2000). Of the stationary state. In W. J. Ashley (Ed.), Principles of Political Economy with some of their Applications to Social Philosophy by J. S. Mill (7th Ed.). London: Longmans, Green \& Co. Retrieved from http://www.econlib.org/library/Mill/mlP61.html\#Bk.IV,Ch.VI.

Minsky, H.P. (1992). The financial instability hypothesis. The Jerome Levy Economics Institute Working Paper \#74. Retrieved from http://papers.ssrn.com/sol3/papers.cfm?abstract id=161024.

Mischel, W., Shoda, Y., \& Rodriguez, M. L. (1989). Delay of gratification in children. Science, 244, 933-938. http://dx.doi.org/10.1126/science.2658056

Monbiot, G. (2009). Newspapers must stop taking advertising from environmental villains. Retrieved from http://www.guardian.co.uk/environment/georgemonbiot/2009/jun/05/climatechange-corporatesocialresponsibility.

Mormon.org. (2009). Television and radio messages for families. Retrieved from http://www.mormon.org/homefront/0,15902,3865-1,00.html.

Murphy, E. S., McSweeney, F. K., Smith, R. G., \& McComas, J. J. (2003). Dynamic changes in reinforcer effectiveness: Theoretical, methodological, and practical implications for applied research. Journal of Applied Behavior Analysis, 36, 421-438. http://dx.doi.org/10.1901/jaba.2003.36-421 


\section{GRANT}

National Bureau of Economic Research. (1929). Recent economic changes in the United States (Vols. 1 and 2). Retrieved from http://www.nber.org/books/comm29-1.

National Research Council. (2007). Coal: Research and development to support national energy policy. Washington, DC: National Academies Press. Retrieved from http://www.nap.edu/openbook.php?record_id=11977.

National Security Council. (1950). NSC 68: United States objectives and programs for national security. Retrieved from http://www.fas.org/irp/offdocs/nsc-hst/nsc-68.htm.

Nell, V. (1988). Lost in a book: The psychology of reading for pleasure. New Haven, CT: Yale University Press.

Nevin, J. (2005). The inertia of affluence. Behavior and Social Issues, 14, 7-20. http://dx.doi.org/10.5210/bsi.v14i1.118

Nicholson, V. (2002). Among the Bohemians: Experiments in living 1900 - 1939. New York: William Morrow.

Norberg-Hodge, H. (1992). Ancient futures: Learning from Ladakh. San Francisco: Sierra Club Books.

Obama, B. H. (2009). Inaugural address. Retrieved from http://www.whitehouse.gov/blog/inaugural-address/.

Packard, V. (1960). The waste makers. New York: Van Rees Press.

Pechmann, C., \& Shih, C. F. (1999). Smoking scenes in movies and antismoking advertisements before movies: Effects on youth, Journal of Marketing, 63, 1-13. http://dx.doi.org/10.2307/1251772

Pew Research Center. (2009). Luxury or necessity? The public makes a u-turn. Retrieved from http://pewsocialtrends.org/assets/pdf/luxury-or-necessity-2009.pdf.

Pierce. L. B. (2003a). The Pierce simplicity study. Retrieved from $\mathrm{http}: / / \mathrm{www}$. gallagherpress.com/pierce/stats.htm.

Pierce, L. B. (2003b). What is voluntary simplicity. Retrieved from http://www.gallagherpress.com/pierce/whatisvs.htm.

Princen, T. (2005). The logic of sufficiency. Cambridge, MA: MIT Press.

Putnam, R. D. (2000). Bowling alone: The collapse and revival of American community. New York: Simon and Schuster.

Rachlin, H. (2000). The science of self-control. Cambridge, MA: Harvard University Press.

Reber, R. A., \& Wallin, J. A. (1984). The effects of training, goal setting, and knowledge of results on safe behavior: A component analysis. Academy of Management Journal, 27, 544-560.

Redman, C. L. (1999). Human impact on ancient environments. Tucson, AZ: University of Arizona Press.

Reich, C. A. (1970). The greening of America. New York: Random House.

Reid, D. G. (1995). Work and leisure in the 21st century: From production to citizenship. Toronto, Canada: Wall \& Emerson.

Richins, M. L. (1991), Social comparison and the idealized images of advertising, Journal of Consumer Research, 18 , 71-83. http://dx.doi.org/10.1086/209242

Rockström, J., Steffen, W., Noone, K., Persson, Å,, Chapin, F. S. III., Lambin, E. F., ...Rogers, P. (2009). A safe operating space for humanity. Nature, 461, 472-475.

Rogers, P. (2008). Facing the fresh water crisis. Scientific American, 299(2), 46-53.

Rosnick, D. \& Weisbrot, M. (2006). Are shorter work hours good for the environment? A comparison of U.S. and European energy consumption. (CEPR Reports and Issue Briefs, 2006-32). Washington, DC: Center for Economic and Policy Research (CEPR). Retrieved from http://ideas.repec.org/p/epo/papers/2006-32.html.

Roszak, T. (1968). The making of a counterculture: Reflections on the technocratic society and its youthful opposition. Garden City, NY: Doubleday. 


\section{SUSTAINABILITY: FROM EXCESS TO AESTHETICS}

Rubin, J. (2009). Why your world is about to get a whole lot smaller: Oil and the end of globalization. Toronto, Canada: Random House Canada.

Rumph, R., Ninness, C., McCuller, G., \& Ninness, S. K. (2005). Guest editorial: Twenty years later, commentary on Skinner's "Why we are not acting to save the world." Behavior and Social Issues, 14, 1-6. http://dx.doi.org/10.5210/bsi.v14i1.117

Russell, B. (1935). In praise of idleness. Retrieved from http://www.awayward.com/library/Philosophy/BertrandRussell/Russell,\%20Bertrand\%20$\% 20 I n \% 20$ Praise $\% 200 f \% 20 I d l e n e s s . p d f$.

Saffer, H., \& Chaloupka, F. (2000). Tobacco advertising: Economic theory and international evidence. Journal of Health Economics, 19, 1117-1137. http://dx.doi.org/10.1016/S0167-6296(00)00054-0

Saffer, H., \& Dhaval, D. (2006). Alcohol advertising and alcohol consumption by adolescents. Health Economics, 15, 617-637. http://dx.doi.org/10.1002/hec.1091

Sanne, C. (2002). Willing consumers--Or locked-in? Policies for a sustainable consumption. Ecological Economics, 42, 273-287. http://dx.doi.org/10.1016/S0921-8009(02)00086-1

Saunders, H. D. (1992) The Khazzoom-Brooks postulate and neoclassical growth. The Energy Journal, 13, 131(18).

Schafer, D. P. (2008). Revolution or Renaissance: Making the transition from an economic age to a cultural age. Ottawa, Canada: Ottawa University Press.

Schor, J. B. (1992). The overworked American: The unexpected decline of leisure. New York: Basic Books.

Schor, J. B. (1995). Can the north stop consumption growth? Escaping the cycle of work and spend. In V. Bhaskar and A. Glyn (Eds.), The north, the south, and the environment: Ecological constraints and the global economy (pp. 68-84). London, U.K.: Earthscan Publications.

Schor, J. B. (1998). The overspent American: Why we want what we don't need. Harper-Collins.

Schumacher, E. F. (1989). Small is beautiful: Economics as if people mattered (Reissued ed.). New York: Harper Perennial.

Scitovsky. T. (1973a). Notes on the producer society. De Economist, 121, 225-250. http://dx.doi.org/10.1007/BF02367126

Scitovsky, T. (1973b). The place of economic welfare in human welfare. Quarterly Review of Economics and Business, 13(3), 7-19.

Scitovsky, T. (1977). Can changing consumer tastes save resources? Journal of Cultural Economics, 1(2), 1-12. http://dx.doi.org/10.1007/BF02427545

Scitovsky, T. (1989a). Human desire and economic satisfaction. New York: New York University Press.

Scitovsky, T. (1989b). Subsidies for the arts: The economic argument. In T. Scitovsky (Ed.) Human desire and economic satisfaction (pp. 149-159). New York: New York University Press.

Scitovsky, T. (1992). The joyless economy: The psychology of human satisfaction (Revised ed.). New York: Oxford University Press.

Shi, D. E. (1985). The simple life: Plain living and high thinking in American culture. New York: Oxford University Press.

Shulman, B. (2008). Punishing workers who must work part-time. Retrieved from http://www.huffingtonpost.com/beth-shulman/punishing-workers-who-mus_b_106819.html.

Skinner, B. F. (1976). Walden two (Reissued edition). New York: Macmillan.

Skinner, B. F. (1978). Are we free to have a future? In B. F. Skinner, Reflections on behaviorism and society (pp. 16-32). Englewood Cliffs, NJ: Prentice-Hall. 


\section{GRANT}

Skinner, B. F. (1987). Why we are not acting to save the world. In B. F Skinner, Upon further reflection, (1-14) Englewood Cliffs, NJ: Prentice-Hall.

Sneddon, A. (2001). Advertising and deep autonomy. Journal of Business Ethics, 33, 15-28. http://dx.doi.org/10.1023/A:1011929725518

Speth, J. G. (2008). The bridge at the end of the world: Capitalism, the environment, and crossing from crisis to sustainability. New Haven, CT: Yale University Press.

Stokes, T. F., \& Baer, D. M. (1977). An implicit technology of generalization. Journal of Applied Behavior Analysis, 10, 349-367. http://dx.doi.org/10.1901/jaba.1977.10-349

Stover, L. (2004). Bohemian manifesto: A field guide to living on the edge. New York: TimeWarner.

Stuart, E. W., Shimp, T. A., \& Engle, R. W. (1987). Classical conditioning of consumer attitudes: Four experiments in an advertising context. Journal of Consumer Research, 14, 334-349.

Swim, J., Clayton, S., Doherty, T., Gifford, R., Howard, G., Reser, J., ...Weber, E. (2009). Psychology and global climate change: Addressing a multi-faceted phenomenon and set of challenges. Retrieved from http://www.apa.org/science/climate-change/.

The National Post. (2009). Don't fight, adapt: We should give up futile attempts to combat climate change. Retrieved from http://www.nationalpost.com/news/story.html?id=164002.

The White House. (2009). Energy \& environment. Retrieved from http://www.whitehouse.gov/issues/energy_and_environment/.

Thoreau. H. D. (1854/1995). Walden; or, life in the woods. New York: Dover.

UNESCO. (2009). The $3^{\text {rd }}$ United Nations world water development report: Water in a changing world. Paris: UNESCO Publishing. Retrieved from http://www.unesco.org/water/wwap/wwdr/wwdr3/index.shtml.

United Nations. (1987). Report of the world commission on environment and development: Our common future. Retrieved from http://www.un-documents.net/wced-ocf.htm.

Wachtel, P. L. (1989). The poverty of affluence: A psychological portrait of the American way of life. Philadelphia: New Society Publishers.

Waide, J. (1987). The making of self and world in advertising. Journal of Business Ethics, 6, 7379. http://dx.doi.org/10.1007/BF00382020

Wakefield, M., Flay, B., Nichter, M., \& Giovino, G. (2003). Role of the media in influencing trajectories of youth smoking. Addiction, 98(S1), 79-103. http://dx.doi.org/10.1046/j.1360-0443.98.s1.6.x

Walker. R. (2008). Buying in: The secret dialog between what we buy and who we are. New York: Random House.

Warren, E., \& Tyagi, A. W. (2003). The two income trap: Why middle-class mothers and fathers are going broke. New York: Basic Books.

Weber, M. (1904/1958). The Protestant ethic and the spirit of capitalism. New York: Charles Scribner's Sons.

Wenger, J. (2001). The continuing problems with part-time jobs. EPI Issue Brief \#155. Retrieved from http://www.epi.org/publications/entry/issuebriefs_ib155/.

Wetzsteon, R. (2002). Republic of dreams Greenwich Village: The American Bohemia, 19101960. New York: Simon \& Schuster.

Wheeler, T. (2004). It's the end of the world as we know it. Retrieved from http://www.baltimorechronicle.com/080304ThomasWheeler.shtml.

Wilson, T. D. (2002). Strangers to ourselves: Discovering the adaptive unconscious. Cambridge, MA: Belnap/Harvard University Press.

Wolf, M. M. (1978). Social validity: The case for subjective measurement or how applied behavior analysis is finding its heart. Journal of Applied Behavior Analysis, 11, 203-214. http://dx.doi.org/10.1901/jaba.1978.11-203

Wordsworth, A. (2009). The Sarkozy doctrine: You're happier than you think. Retrieved from 


\section{SUSTAINABILITY: FROM EXCESS TO AESTHETICS}

http://network.nationalpost.com/np/blogs/fullcomment/archive/2009/09/15/sarkozy-wantsthe-french-to-pursue-more-happiness.aspx

Worm, B., Barbier, E. B., Beaumont, N., Duffy, J. E., Folke, C., Halpern, B. S., ...Watson, R. (2006). Impacts of biodiversity loss on ocean ecosystem services. Science, 314, 787-790. http://dx.doi.org/10.1126/science.1132294

Zimbalist, A. S. (1999). Unpaid professionals: Commercialism and conflict in big-time college sports. Princeton, NJ: Princeton University Press. 